\title{
Quality Attributes of IMF Halwa Prepared from White Gourd (Banincasa hispida)
}

\author{
Sangita Sood* \\ Department of Food Science and Nutrition, College of Home Science, India \\ Submission: October 26, 2016; Published: November 16, 2016 \\ *Corresponding author: Sangita Sood, Department of Food Science and Nutrition, College of Home Science, India, \\ Email: sangitasood@rediffmail.com
}

\begin{abstract}
Halwa, a traditional sweet is now not only preferred for its taste and caloric enrichment but also providing a much needed home touch to war fighting forces. Diabetics who have strong passion for sweets can even relish Halwa preferred by using orbital as a substitute for sugar. The vegetable halwa prepared by using different humectants extremely relished by all judges. IMF white gourd halwa by using different humectants viz. sugar $\left(\mathrm{WHT}_{0}\right)$, glycerol $\left(\mathrm{WHT}_{1}\right)$, honey $\left(\mathrm{WHT}_{2}\right)$ and sorbitol $\left(\mathrm{WHT}_{3}\right.$ at a concentration of 50.0 per cent. The prepared product is evaluated for various parameters.
\end{abstract}

Keywords: Halwa; Humectants; Diabetics; Traditional sweet

\section{Introduction}

India is homes of traditional sweets form an integral part of the festivities in the villages and small towns. Exchange of these fresh sweets is a symbol of brotherhood and helps in binding the society into a unique bond. Although, there constitute an age-old small-scale industry where, traditional recipes are guarded as trade secrets and passed on from generation. Some areas have uniqueness of tastes a particular recipe and basically use only 3-4 locally available ingredients like cereal flour; milk, legumes, sugar and ghee are used. If some kind of mechanization and standardizations of products can be brought about using a combination of traditional art and modern scientific methods, development of new products with longer shelf-life could become a possibility for spreading the marketing net - work. This would also be integrated with the on - going economic enlistment programmed launched from time to time.

A recant development has been in the form of a highly nutrition's vegetable halwa which is not only preferred for its taste and caloric enrichment but also for providing a much needed home touch and caloric enrichment but also for providing a much needed home touch to the war weary soldiers at front. Because such products could really become morale booster and a source of changed taste buds of our weary soldiers fighting in difficult terrains. Halwas using various ingredients varying form flour to vegetable and fruits would fit very well in this category.
White gourd (Banincas hispid a). This is either used for the production of candy or used as vegetable and made into curries. Since it is abundantly grown locally and in the present studies, an effort was made to standardize IMF hawla suiting to the India palate.

\section{Materials and Methods}

White gourd was procured from the local growers for the production of IMF halwa. The halwa was prepared by using component-blending technique. This technique represents the principal method off economical importance where all the IMF commonest were weighed, blended and cooked to give the finished product desired water - activity. The recipe used for the production of halwa is mentioned below:

\section{Recipe}

Ingredients
a. White gourd shreds $100.0 \mathrm{~g}$
b. Oil/ ghee $10.0 \mathrm{~g}$
c. Milk 50.0g
d. Humectants $50.0 \mathrm{~g}$
e. Potassium sorbate 0.1 per cent 


\section{Method}

White gourd is washed, peeled and cut. Into big pieces and dipped into 1.0 per cent $\mathrm{CaCl}_{2}$ solution for 2-3 hours. Then washed under running water to remove the traces. In addition to sugar, glycerol, honey and sorbitol were also attempted to use as a substitute for sugar. The uses of honey with therapeutic values are fruits time tried for the production of such sweets. Whereas, sorbitol based halwa can be relished by diabetics who otherwise were restricted to low sugar intake. Detailed unit-operations are depicted in Figure 1.

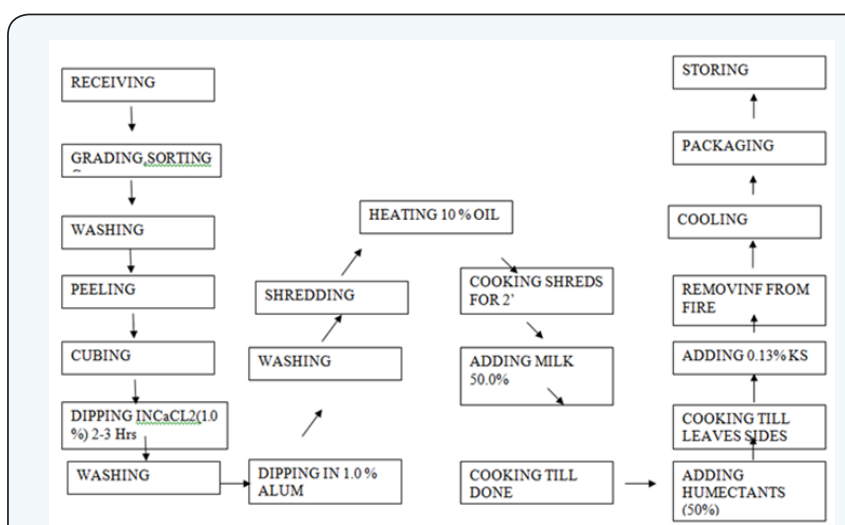

Figure 1: Unit Operations Involved In the Preparation of IMF Halwa.

Different humectants viz. sugar $\left(\mathrm{WHT}_{0}\right)$, glycerol $\left(\mathrm{WHT}_{1}\right)$, honey $\left(\mathrm{WHT}_{2}\right)$ and sorbitol $\left(\mathrm{WHT}_{3}\right)$ were used at a concentration of 50.0 per cent. Table 1 illustrates the treatments and interactions. The prepared product was evaluated for various quality attributes by using standard procedures. And the parameters studied were moisture, crude protein true protein non - protein nitrogen [1], Calorific value, O'Shea, Mayure et al. [2] TSS, pH, per cent Acidity, Sugars, Ascorbic acid, SO2, NEB and Pectin by using standard methods as described by Rangana s et al. [3].

\section{Results and Discussion}

(Table $1 \& 2$ ) illustrates the quality attributes of IMF white gourd halwa. Different humectants viz. sugar (WHTO), glycerol $\left(\mathrm{WHT}_{1}\right)$, honey $\left(\mathrm{WHT}_{2}\right)$ and sorbitol $\left(\mathrm{WHT}_{3}\right)$ were used at a concentration of 50.00 per cent A perusal of data depicted in Tables 1 shows that among four different humectants, the treatment $\mathrm{WHT}_{2}$ obtained the maximum moisture (12.40\%) followed by $\mathrm{WHT}_{1}$ (10.80)), $\mathrm{WHT}_{0}$ (9.80) and $\mathrm{WHT}_{3}$ (7.60) per cent respectively. Statistically all the treatments differed significantly. The maximum moisture in treatments $\mathrm{WHT}_{2}$ and $\mathrm{WHT}_{1}$ was due to their inherent moisture, but reduced comparatively less by evaporation during cooking. In the present findings, the moisture ranged from 7.60-12.40 per cent. However, Sampathu et al. [4] also observed the moisture in carrot halwa in the range of 14.00-41.20 per cent. The present results are within the reported range. On a critical look at data in the same table reveals that honey supplemented sample had attained the maximum value which is due to high amount of nitrogen in honey .The same observation was also shared by Singh and associate in 1981. All the treatments differed significantly among themselves for the same parameter.

Table 1: Treatment Sub-treatments and their interactions (IMF White Gourd Halwa).

\begin{tabular}{|c|c|c|}
\hline Control & Treatments & Interactions \\
\hline Sugar & $\mathrm{T}_{0}$ & $\mathrm{WHT}_{0}$ \\
\hline Glycerol & $\mathrm{T}_{1}$ & $\mathrm{WHT}_{1}$ \\
\hline Honey & $\mathrm{T}_{2}$ & $\mathrm{WHT}_{2}$ \\
\hline Sorbitol & $\mathrm{T}_{3}$ & $\mathrm{WHT}_{3}$ \\
\hline
\end{tabular}

Table 2: Effect of Different treatments on the Quality Attributes of Freshly Prepared IMF White Gourd Halwa.

\begin{tabular}{|c|c|c|c|c|c|}
\hline Treatments & $\begin{array}{c}\text { Moisture } \\
\text { (\%) }\end{array}$ & $\begin{array}{c}\text { Crude } \\
\text { Protein } \\
\mathbf{( \% )}\end{array}$ & $\begin{array}{c}\text { True } \\
\text { Protein } \\
\mathbf{( \% )}\end{array}$ & $\begin{array}{c}\text { Non } \\
\text { protein } \\
\mathbf{( \% )}\end{array}$ & $\begin{array}{c}\text { Energy } \\
\text { Kcals) } \\
\mathbf{1 0 0 g}\end{array}$ \\
\hline $\mathrm{WHT}_{\mathrm{o}}$ & 9.80 & 1.91 & 1.33 & 0.58 & 1028.61 \\
\hline $\mathrm{WHT}_{1}$ & 10.80 & 1.86 & 1.75 & 0.11 & 829.22 \\
\hline $\mathrm{WHT}_{2}$ & 12.40 & 2.38 & 2.00 & 0.38 & 865.24 \\
\hline $\mathrm{WHT}_{3}$ & 7.60 & 1.49 & 1.01 & 0.48 & 710.12 \\
\hline $\mathrm{CD}$ & 0.52 & 0.084 & 0.10 & 0.15 & 13.96 \\
\hline
\end{tabular}

True protein was also maximum in honey based sample. Sugar treated halwa obtained the maximum (1028.68Kcals) value and minimum (710.12) was attained by $\mathrm{WHT}_{3}$, whereas, honey and glycerol based sample observed the intermediate values. High caloric value obtained by WHT0 was due to maximum energy per gram released by sucrose. Higher energy value shown by WHT2 was due to high caloric content contributed by honey as it was also rich in fatty acids Shamala, Jyothi et al. [5]. Whereas; low calories contributed by sorbitol based sample can be a good source for diabetics.

Table 3: Effect of Different Treatments on the Quality Attributes of Freshly Prepared IMF White Gourd Halwa.

\begin{tabular}{|c|c|c|c|c|c|c|c|c|}
\hline Treatments & TSS & $\mathbf{p H}$ & $\begin{array}{c}\text { Acidity (CA } \\
\mathbf{\%})\end{array}$ & $\begin{array}{c}\text { Total Sugars } \\
\mathbf{( \% )}\end{array}$ & $\begin{array}{c}\text { Ascorbic } \\
\text { acid } \\
\mathbf{m g} / \mathbf{1 0 0 g}\end{array}$ & S02 ppm & $\begin{array}{c}\text { NEB ODxDF } \\
\text { Pectin \% Ca } \\
\text { pectate }\end{array}$ \\
\hline $\mathrm{WHT}_{0}$ & 32.00 & 5.65 & 0.178 & 55.47 & 16.78 & 76.20 & 0.462 & 0.82 \\
\hline $\mathrm{WHT}_{1}$ & 40.00 & 5.82 & 0.167 & 7.62 & 14.79 & 28.40 & 0.223 & 0.92 \\
\hline $\mathrm{WHT}_{\mathrm{WHT}}$ & 38.00 & 4.35 & 0.366 & 41.54 & 15.06 & 43.87 & 0.210 & 0.61 \\
\hline $\mathrm{CD}$ & 38.00 & 5.67 & 0.192 & 7.52 & 12.43 & 64.60 & 0.265 & 0.41 \\
\hline
\end{tabular}


The data for other nutritional parameters is given in Table 3 and it is clear from the same table that as far TSS is concerned, the glycerol based halwa secured the maximum degrees Brix followed by honey and sorbitol treated samples. The treatments prepared by sugar, glycerol and honey differed significantly whereas; sorbitol and honey remained statistically at par with each other. Information on $\mathrm{pH}$ reveals that the honey based sample obtained the value on the lower side due to inherent acidity of the honey in comparison to other humectants based samples. The values in $\mathrm{pH}$ between sugar and honey varied non-significantly. Whereas, honey-glycerol, glycerol and sorbitol varied significantly.

Acidity was estimated as per citric acid. Honey treated sample had the maximum due to the inherent acidity of honey followed by sorbitol, sugar and glycerol. The minimum value in glycerol is due to its own sweetness. Sugar based halwa obtained the maximum total sugars due to the high sucrose followed by honey, while in glycerol and sorbitol treated samples the values remained statistically at par. Whereas, sugar, glycerol, honey and sorbitol differed significantly. Ascorbic acid is an important vitamin with anti oxidental property. The values varied from $12.43-16.78 \mathrm{mg} / 100 \mathrm{~g}$. All the treatments remained statistically at par. Sulphur dioxide content was found to be more in sugar treated sample and minimum in case of glycerol treated samples. Although honey contributed significantly better than sorbitol,the sulphur dioxide residual in case of sugar based halwa is due to the sulphur containing preservatives used in the beggase preparation, juice preservation and fining agent in the preparation of sugar.

The data on non-enzymatic browning is of little consequence in the preparation and evaluation of halwa. On visual examination; it is observed that the colour of the produce remained unaffected till ten days when packaged in different containers. As far as per cent pectin is calculated as calcium pectate, all the treatments obtained the values at a significant difference. It is inferred that White Gourd can be use for the development of halwa and sorbitol treated halwa can be enjoyed be diabetics which brighten their scope in the market.

\section{References}

1. AOAC (1990) Approved methods methods of Association of Official analytical Chemists, Washington DC, USA.

2. O Shea J, Manure MF (1962) Domination of calorific Value of foodstuff by chromic acid Oxidation. Journal of Food Science and Agricultural 13: 350.

3. Rangana S (1995) Handbook of Analysis and Quality Control for Fruits and Vegetable Products. ( $2^{\text {nd }}$ edn), Tate Mc Grew Hill publishing Co. Ltd., New Delhi, India.

4. Sampathu SR, Chakaraborty S, Prakash Kamal, Bisht HC, Agarwal MD, et al. (1981) Standardization and preparation of Carrot halwa - an Indian Sweet. Indian Food packer 35: 60-67.

5. Shamala TR, Jyothi Y Shri (1999) Honey-It is more than just sweet. Indian Food Industry 18: 349-355.

Your next submission with JuniperPublishers will reach you the below assets

- Quality Editorial service

- Swift Peer Review

- Reprints availability

- E-prints Service

- Manuscript Podcast for convenient understanding

- Global attainment for your research

- Manuscript accessibility in different formats ( Pdf, E-pub, Full Text, Audio)

- Unceasing customer service

Track the below URL for one-step submission http://juniperpublishers.com/online-submission.php 